\title{
Diaphragmatic Rupture an Emergency Case Report
}

\author{
Ifada Indriyani ${ }^{1}$, Widiastuti ${ }^{1}$, Tharina Lawei ${ }^{1}$, Darmawan Ismail ${ }^{2}$ \\ 1. Department of Radiology, Dr. Moewardi Hospital/ Faculty of Medicine, Universitas Sebelas Maret, \\ Surakarta \\ 2. Department of Cardiovascular and Thoracic Surgery, Dr. Moewardi Hospital/ Faculty of Medicine, \\ Universitas Sebelas Maret, Surakarta
}

Coresponding author : ifada_indriyani@yahoo.co.id

\begin{abstract}
Introduction: Diaphragmatic rupture is a major challenge for the radiologist to be confirmed as an emergency diagnosis. The prevalence of the injury is 5\% of abdominal blunt force trauma cases. Left-sided injury is more common with left-to-right ratio 3:1. Chest X-Ray is a conventional modality as an early assessment of abdominal trauma and computed tomography is a standard reference to confirm this diagnosis.

Case Report: A 70 yo man complained about chest pain after falling from 4 meter-height tree. Chest X-Ray revealed bowel gas appearance in the left thorax cavity with no appearance of left diaphragm. Contrasted abdominal CT showed gaster and intestine in the left thorax cavity. The patient underwent left diaphragm thoracotomy confirming the existence of gaster, ileum, and spleen in the pleural cavity. Those organs were returned to the abdomen and the left diaphragm repaired. Following-up after discharge obtained remarkable outcomes.

Discussion: Confirming the diagnosis of diaphragmatic rupture is a challenge for the radiologist because it can be asymptomatic until life-threatening complications manifest such as respiratory disorders and visceral incarceration.

Conclusion: With the improvement of imaging technology, the radiologist is able to confirm a diaphragmatic rupture to get a better prognosis.
\end{abstract}

Key words: diaphragmatic rupture; trauma; chest X-ray; computed tomography

\begin{abstract}
ABSTRAK
Pendahuluan : Konfirmasi diagnosis emergensi ruptur diafragma masih menjadi tantangan bagi spesialis radiologi. Prevalensi ruptur diafragma sebesar 5\% dari kasus trauma tumpul abdomen dan perlukaan diafragma pada sisi kiri lebih umum terjadi dibandingkan sisi kanan dengan rasio 3:1. Foto X-Ray dada merupakan modalitas konvensional sebagai penilaian awal trauma abdomen dan computed tomography scanning (CT scan) merupakan standar pemeriksaan untuk mendiagnosis kasus tersebut.

Laporan Kasus : Seorang laki-laki berusia 70 tahun mengeluhkan nyeri dada setelah jatuh dari pohon setinggi 4 meter. X-ray dada menunjukkan gambaran gas usus di sebelah kiri rongga thorax dan tidak tampak gambaran diafragma kiri. CT scan abdomen dengan kontras menunjukkan gambaran lambung dan usus di sebelah kiri rongga thorax. Pasien tersebut kemudian ditatalaksana dengan thorakotomi diafragma kiri untuk mengkonfirmasi adanya lambung, ileum dan lien pada rongga pleura. Organ-organ tersebut kemudian dikembalikan ke dalam abdomen dan diafragma kiri direparasi. Kondisi klinis pasien setelah penatalaksanaan tersebut menunjukkan perbaikan.

Diskusi : Konfirmasi diagnosis ruptur diafragma merupakan tantangan bagi spesialis radiologi karena kasus tersebut bisa tidak bergejala sampai timbulnya komplikasi yang mengancam jiwa seperti gangguan respirasi dan perlekatan organ visceral.

Kesimpulan : Dengan adanya perkembangan teknologi pencitraan, spesialis radiologi dapat mengkonfirmasi ruptur diafragma sehingga memberikan prognosis yang lebih baik.
\end{abstract}

Kata Kunci : ruptur diafragma; trauma; chest X-ray, computed tomography 


\section{INTRODUCTION}

The diaphragm is the crucial muscle of inspiration, responsible for about two thirds of the respiration in healthy humans ${ }^{1}$. In a healthy adult with an essential volume of 4.5 liters, some 3 liters are reported for by diaphragmatic excursion ${ }^{1}$. Diaphragmatic rupture is a major challenge for the radiologist to be confirmed as an emergency diagnosis due to the shortcoming of distinct clinical signs ${ }^{1-5}$. The prevalence of the injury is $5 \%$ of abdominal blunt force trauma cases ${ }^{1-5}$. Left-sided injury is more common with left-to-right ratio $3: 1^{5-7}$. The injury can be asymptomatic until lifethreatening complications manifest ${ }^{8}$. Associated abdominal injury is typical during blunt trauma and may overshadow the presentation of a complementary diaphragmatic rupture ${ }^{1}$.

The complications can be respiratory disorders and visceral incarceration ${ }^{3-5,7-9}$. Spleen, the left colon or the stomach are the most frequently incarcerated organs ${ }^{3-5,7-9}$. Chest radiography is a conventional modality as an early assessment of abdominal trauma and computed tomography is a standard reference to confirm this diagnosis ${ }^{1-10}$.

\section{CASE REPORT}

A 70 years old man was admitted to the emergency department of Dr. Moewardi General Hospital. The patient complained about shortness of breath and chest pain after falling from 4 meter-height tree a few days ago. The thorax was asymmetrical on the left side with bowel sounds heard. The remaining physical examination proved remarkable. Chest radiography revealed upward displacement of small bowel gas appearance in the left thorax cavity with no appearance of left diaphragm. Abdominal contrast-enhanced CT showed gaster, intestine, left lung collapse, right lung contusion, spleen and left kidney injury in the pleural cavity with torn left diaphragm. The patient underwent left diaphragm thoracotomy confirming the existence of gaster, ileum, and spleen in the pleural cavity. Those organs were returned to the abdomen and the left diaphragm repaired. Following-up after discharge obtained remarkable outcomes.

\section{DISCUSSION}

The predominance of diaphragm ruptures occurs through the left diaphragm (8895\%) due to the protective effects of the liver under the right diaphragm ${ }^{1-10}$. Blunt trauma to the abdomen will boost the gradient of transdiaphragmatic stress between the abdominal compartment and therefore the thorax ${ }^{1,2,7}$. This leads the diaphragm's stretched membrane to be cut off from its points of attachments due to an intra-abdominal pressure eruption that is transferred through the entrails ${ }^{1,2,7}$. Diaphragmatic rupture consists of 3 stages $^{4,6,7,9,10}$. The first stage is an acute phase in which the diaphragm is injured at the moment ${ }^{4,6,7,9,10}$. The delayed stage is associated with temporary visceral herniation, thus accounting for non-specific lack or intermittent symptoms ${ }^{4,6,7,9,10}$. The obstruction stage indicates long-standing herniation issues that appear as obstruction, strangulation, and rupture ${ }^{4,6,7,9,10}$.

Diaphragmatic rupture occurs in herniation of intraabdominal structures including the loops of the colon, gaster, liver, spleen and small intestines ${ }^{3,7-9}$. Following a diaphragmatic rupture, the main pathophysiologyis an insufficiency of the diaphragm, compression of the lungs from herniated viscera, mediastinal displacement and decreased venous return ${ }^{1,7}$. The problems vary from obstruction to strangulation, or viscera ruptured ${ }^{4,6,7,9,10}$. It is essential that diaphragmatic rupture is diagnosed early.

Early diagnosis may be difficult owing to remarkable physical examination, and 30 50 percent of diaphragmatic ruptures are 
overlooked on original imaging and related lesions that may mask their existence ${ }^{1,3}$. Failure to recognize diaphragmatic rupture quickly, with subsequent herniation, may lead to postponed symptoms with possibly disastrous results ${ }^{10}$.

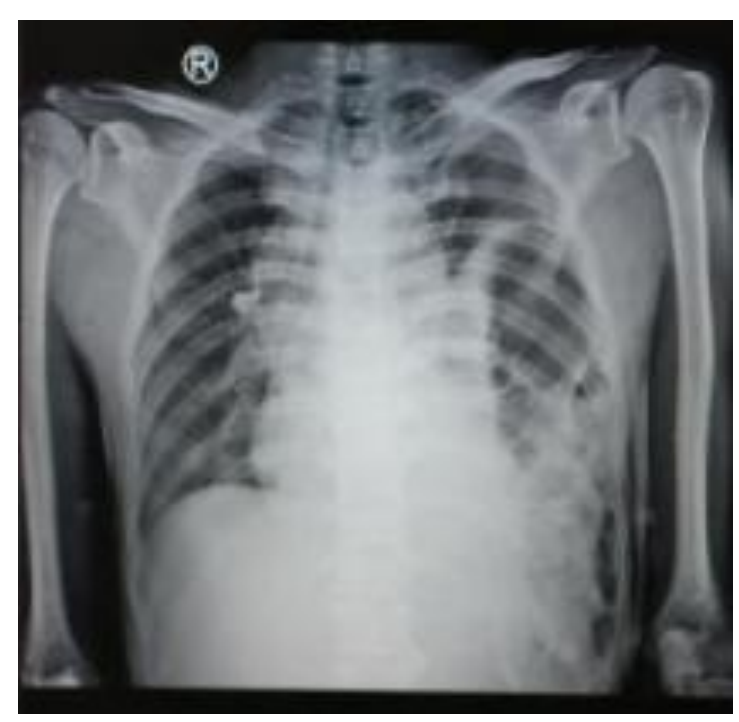

Figure 1. Chest radiography showed bowel gas appearance in the left thoracic cavity with no appearance of the left diaphragm

In the acute stage, chest radiography remains useful for detecting of diaphragm injury, despite its technical limitations including supine positioning, use of portable radiography and limited patient cooperation $^{6,7,9,10}$. The non-specific radiography results may include rib fractures, hemo-or pneumothorax, and atelectasis at the lung bases $^{2-7,9}$. Specific results are hemidiaphragm asymmetry or shifitng levels of the hemidiaphragm, intrathoracic herniation of the hollow viscus with or without the focal constriction of the viscus at the shear locations (collar sign), and visualization of the nasogastric tube above the hemidiaphragm on the left side ${ }^{2-7,9}$.

In addition to showing any abdominal organs herniated through the rupture, CT axial scans combined with the high-quality coronal and sagittal reformations may show large and small ruptures of the diaphragm. Specific CT indications for diaphragm injury include immediate visualization of injury, nonvisualization of segmental diaphragm, intrathoracic visceral herniation, the collar sign, dependent viscera sign, diaphragm thickening, and peri diaphragmatic active contrast extravasation ${ }^{3,5,9,10}$.

Directly visualization of the injury is demonstrating the free edge of the disrupted diaphragm demarcating the defect $^{3,5,9,10}$. Isolated segmental non-visualization of the diaphragm is highly sensitive, but when viewed in isolation, this sign must be used with caution, especially in the elderly, in whom it may be a normal variant ${ }^{3,5,9,10}$. Intrathoracic herniation of viscera has high specificity but has variable sensitivity. If an abdominal structure herniates through a diaphragm rent, the free edges of the diaphragm may restrict the herniated organ, and resulting in a "collar". The dependent viscera sign and the collar sign are reported to be $100 \%$ specific $^{2,3,5,9}$.

The collar sign is indicated when a hollow viscus, commonly the stomach, appears to occupy partially within the thorax and is kinked as it passes through the expected plane of the diaphragm ${ }^{2,3,5,10}$. The dependent viscera sign is recognized on axial view CT when the upper third of the liver or spleen is in contact with the posterior thoracic wall ${ }^{2,3,5,10}$. These structures are normally suspended away from the posterior wall to their superior extent by the presence of an intact diaphragm ${ }^{2,3,5,10}$. 

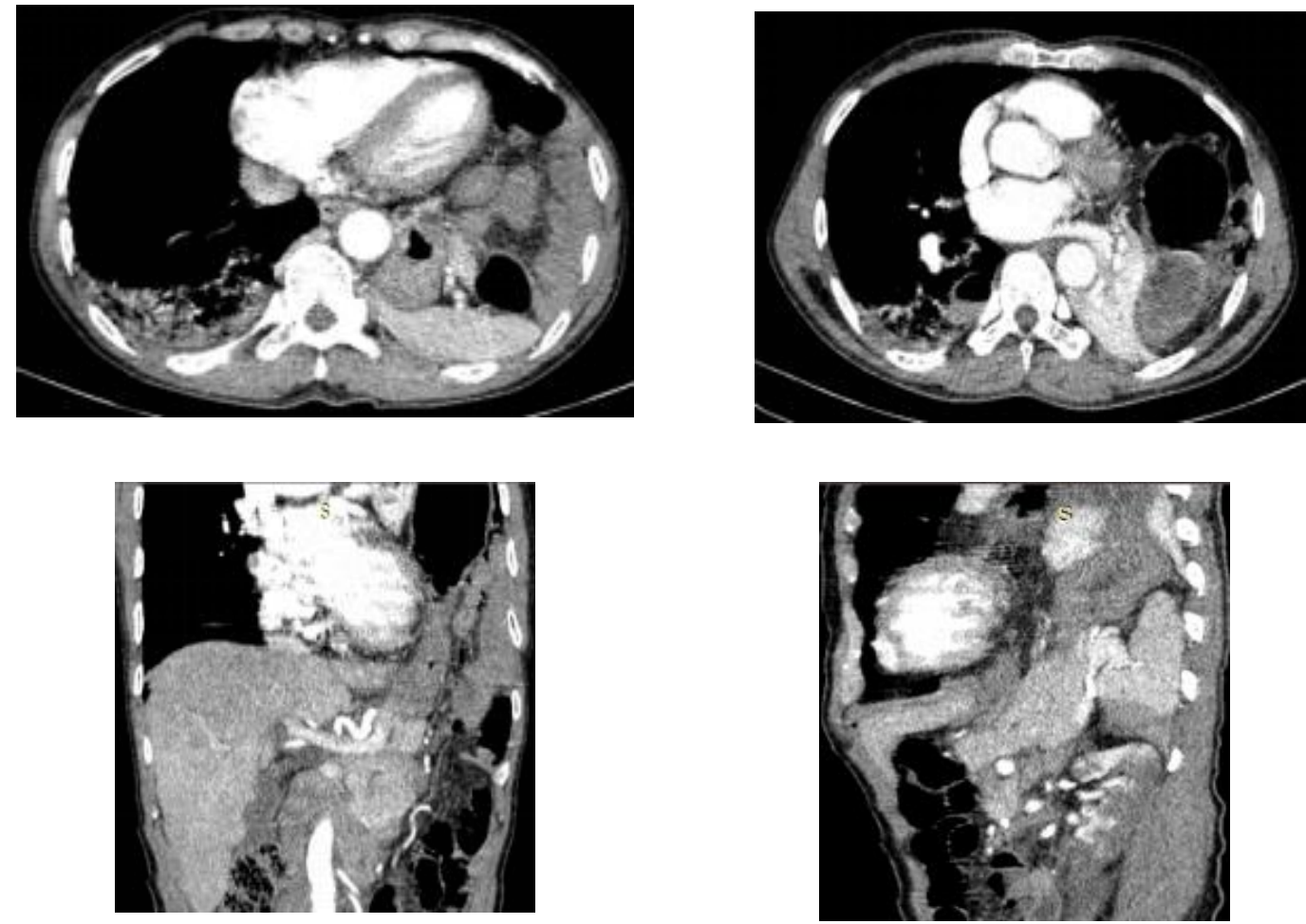

Figure 2. Abdominal CECT. The axial view showed 'dependent viscera sign' with the stomach, small bowel loop and spleen in the left pleural cavity with left lung collapse and right lung contusion. The sagittal and coronal view revealed the extent of left diaphragm rupture with thickened and retracted torn diaphragm, accompanied by spleen and left kidney injury.

\section{CONCLUSION}

Diaphragmatic rupture as a consequence of blunt abdominal trauma is not only rare but also possibly underdiagnosed. In the case of a absence of indicative signs and radiographic results, these constraints must be met in order to reach the appropriate diagnosis. In order to get a better prognosis, the radiologist can verify a diaphragmatic rupture with the improvement of imaging technology.

\section{REFERENCES}

1. Korse Balde A. A Case Report on Diaphragmatic Rupture, in the Visceral Surgery of Hospital of Conakry, Guinea. J Surg. 2016;4(3):76.
2. Kishore A, Singh A, Jain A. Traumatic diaphragmatic hernia: a case report. Int Surg J. 2018;5(6):2375.

3. McCloud TC, Boiselle PM, editors. The Requisites Thoracic Radiology. 2nd ed. Philadelphia: Elsevier Health Sciences; 2010.

4. Reddy SV, Anuradha B, Sushma P, Jagadeesh AB, K Varun Prakash. Traumatic Diaphragmatic Hernia: A Case Report. Int J Sci Study. 2015;3(6):241-3.

5. Soto JA, Lucey BC, editors. The Requisites Emergency Radiology. 2nd ed. Philadephia: Elsevier Health Sciences; 2017.

6. Kahwa A Al. Blunt Diaphragmatic Rupture a Case Report and Literature Review. Emerg Med Open Access. 2016;6(4). 
7. Rashid F, Chakrabarty MM, Singh R, Iftikhar SY. A review on delayed presentation of diaphragmatic rupture. World J Emerg Surg. 2009;4(1):32.

8. Nguyen P, Davis B, Tran DD. Laparoscopic Repair of Diaphragmatic Rupture: A Case Report with Radiological and Surgical Correlation. Case Rep Surg. 2017;2017:1-4.

9. Veena Chowdhury, Arun Kumar Gupta NK. Diagnostic Radiology Chest and Cardiovascular Imaging. Jaypee Brothers Medical Publishers (P) LTD. 2010.

10. Kaur R, Prabhakar A, Kochhar S, Dalal U. Blunt traumatic diaphragmatic hernia: Pictorial review of CT signs. Indian J Radiol Imaging. 2015;25(3):226. 